\title{
Genetic Diversity in Natural Populations and Cultivated Stands of Walnut (Juglans regia L.) Using Microsatellite Marker
}

Chonur Mohammadi ${ }^{1}$

https://orcid.org/0000-0001-5715-6653

\section{Nasrin Seyedi ${ }^{*}$}

https://orcid.org/0000-0003-4999-7879

Babak Abdollahi Mandoulakani ${ }^{2,3}$

https://orcid.org/0000-0003-3825-2759

\section{Maria Filomena Caeiro ${ }^{4}$ \\ https://orcid.org/0000-0003-0559-6344}

${ }^{1}$ Urmia University, Faculty of Natural Resources, Department of Forestry, Urmia, West Azerbaijan, Iran; ${ }^{2}$ Urmia University, Faculty of Agriculture, Department of Plant Production and Genetics, Urmia, West Azerbaijan, Iran; ${ }^{3}$ Urmia University, Institute of Biotechnology, Department of Agricultural Biotechnology, Urmia, West Azerbaijan, Iran; ${ }^{4}$ Universidade de Lisboa, Faculdade de Ciências, Departamento de Biologia Vegetal, Centro de Estudos do Ambiente e do Mar (CESAM), Lisboa, Portugal.

Editor-in-Chief: Alexandre Rasi Aoki

Associate Editor: Ivo Mottin Demiate

Received: 2020.11.25; Accepted: 2021.06.07.

*Correspondence: n.seyedi@urmia.ac.ir, n.seyedi@gmail.com; Tel.: +98-44-32770489 (N.S.).

HIGHLIGHTS

- Planted stands can be used for extending and preserving the genetic diversity of natural stands.

Abstract: Information on genetic diversity is fundamental to developing in situ or ex situ conservation strategies. This study assessed the genetic differentiation between plantations and neighboring natural populations of Juglans regia. Genetic structures of three natural population and three neighboring plantations of $J$. regia in northwest of Iran were assessed using 10 nuclear microsatellite loci (SSR). Natural populations presented higher total number of alleles $(119)$ and observed heterozygosity $(\mathrm{Ho}=0.29)$ than planted stands (101 alleles, $\mathrm{Ho}=0.21$ ). The observed alleles of natural stands varied from 2 (WGA61 and WGA9) to 7 (WGA9) and from 2 (WGA321 and WGA276) to 5 (WGA202 and WGA9) in planted stands. One of the planted populations (B) indicated the largest level of genetic diversity. In conclusion, genetic diversity of all investigated plantation and natural stands are similar. This recommends that even plantations might qualify as gene conservation stands.

Keywords: Juglandaceae; SSR markers; Observed heterozygosity. 


\section{INTRODUCTION}

There is wide consensus that ongoing deforestation contributes to global warming and poses a threat to species diversity. Less understood is whether the practice of creating plantations might also erode genetic diversity and undermine the genetic structure of tree populations. Globally, planted forests make up about $7 \%$ of the world's total forest area [1]. In contrast to natural populations, planted trees are specifically selected for their favorable traits, a process that may result in a decrease in genetic diversity in the following generations and an undermining of local adaptation in native populations [2].

With growing concern about maintenance of genetic diversity and preservation of gene resources, the question arises on the extent to which a planted population should be considered a gene resource able to preserve the gene pool of the original populations [3].

The maintenance of genetic diversity and evolutionary adaptive potential of planted forests is an important issue if it is planned to use reproductive material from these plantations, such as by its conversion to a seed production area [4] or by using natural regeneration for the establishment of the next generation. Monitoring genetic diversity parameters of planted forests can help to evaluate whether forest establishment may contribute to the conservation of the species' gene pool [3]. However, the monitoring of genetic diversity, has been disregarded in all forest monitoring plans up to now, mainly because genetic diversity was expensive and difficult to measure directly [5].

The introduction of molecular biology techniques, such as DNA based markers, provides an opportunity for genetic characterization that allows direct comparison of different genetic material independent of environmental influences [6]. Simple sequence repeat (SSR), an array of short motifs of $1-6$ bp in length, are hypervariable and widely spread in both coding and non-coding regions of plant and animal genomes [7]. The numbers of core repeats are variable, presumably due to strand slippage during DNA replication or unequal exchange in meiosis. Because of the high mutability, SSR located regions are thought to play significant roles in genome evolution by creating and maintaining quantitative genetic diversity [8]. The reproducibility, multiallelism, codominance, relatively abundance and wide genome coverage of SSR markers have made them one of the most useful tools for integration of the genetic, physiological and sequencebased physical maps in plant species [9].

In this study we focused on the analysis of the genetic diversity in plantations of Juglans regia L. (Persian walnut) established in northwest of Iran, in comparison with natural populations of the same region. The species is a diploid $(2 n=32)$ monoecious tree that is native to the mountain chain of Central Asia and grows as wild or semi-cultivated trees in a wide area from south-eastern Europe and the Caucasus to Turkey and Iran, through southern portions of the former Soviet Union into China and the eastern Himalayas. Persian or English walnut is an agroforestry species that is highly valued for its high-quality wood and energy-rich nutmeats. Its nuts are easily stored and transported over long distances [10]. In addition, J. regia is the most economically important species from all the 21 species belonging to the genus Juglans and is the only species widely cultivated for its edible nuts [11].

Juglans regia is in the near threatened class of the IUCN Red List of Threatened Species [12]. In the present study, four hypotheses were formulated: (i) the different origin of natural and planted populations is reflected by different genetic structures; (ii) plantations show lower levels of genetic diversity than natural populations due to bottlenecks during the harvesting of reproductive material and raising of seedlings; (iii) genetic differentiation between plantations and neighboring natural populations is high; and (iv) genetic diversity is spatially structured in natural populations, i.e. distantly located natural populations are genetically more differentiated from each other than neighboring populations, but not in plantations.

\section{MATERIALS AND METHODS}

Samples were collected from three natural stands and three planted stands near the natural populations. All stands were close to each other and the maximum distance between the stands was $10 \mathrm{~km}$. They were

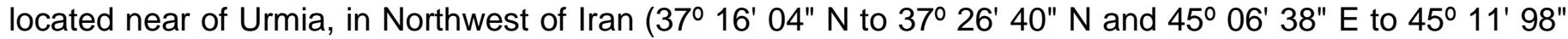
E). Natural stands were sampled from Dostak (DSK), Pole Najdare (PLN), and Dare Khan (DKH) and the plantations were sampled near them (A, B and C). Ten trees from each population were selected. In natural stands the first tree was selected randomly and the next at the distance of double tree high of the previous sampled tree. In the planted stands all the samples were collected randomly. At Least six young leaves from each tree were collected in spring and stored at $-80^{\circ} \mathrm{C}$ for DNA extraction. 


\section{DNA extraction and SSR analysis}

Genomic DNA was extracted from all 60 samples using the CTAB method [13] by grinding 100-150 mg of leaf tissue in a $2 \mathrm{ml}$ micro-centrifuge tube containing a $700 \mu \mathrm{L}$ extraction buffer. DNA quality and quantity were determined spectrophotometrically and by electrophoresis on $1 \%$ agarose gels stained by ethidium bromide [11].

Ten microsatellite loci (WGA001, WGA004, WGA009, WGA069, WGA071, WGA089, WGA118, WGA202, WGA276, WGA321) already sequenced and used for the preliminary genetic characterization of J. regia were amplified in all samples [14,15] (Table 1).

Polymerase chain reaction (PCR) was performed using 20 ng genomic DNA, PCR buffer 10X, $\mathrm{MgCl}_{2} 25$ $\mathrm{mM}, 0.2 \mathrm{mM}$ of each dNTP, 1 unit of Tag DNA polymerase and $1 \mu \mathrm{M}$ of each forward and reverse primers (Cinaclon, Iran). Total reaction volume was $20 \mu \mathrm{L}$. Reactions were performed in a Thermocycler (Applied Biosystem, USA) according to the following procedure: preheating for $5 \mathrm{~min}$ at $94{ }^{\circ} \mathrm{C}, 35$ cycles of $50 \mathrm{~s}$ at $94^{\circ} \mathrm{C}$ (denaturation), $40 \mathrm{~s}$ at $57^{\circ} \mathrm{C}$ to $60^{\circ} \mathrm{C}$ (annealing) and $1 \mathrm{~min}$ at $72{ }^{\circ} \mathrm{C}$ (extension), and final extension at $72{ }^{\circ} \mathrm{C}$ for $7 \mathrm{~min}$.

PCR products were separated in $3 \%$ agarose gels with at 70 volts for $3-4$ hours in TBE buffer. Allele sizing and scoring was done using $50 \mathrm{bp}$ DNA ladder (Fermentas, USA) as the length reference.

\section{Data analysis}

The presence and absence of bands were scored as 1 or 0 respectively for each individual. We used GENALEX 6.4 software to study the genetic diversity in natural and planted stands by SSR markers [16]. For each population of $J$. regia, genetic diversity was estimated based on standard genetic parameters: number of alleles $(\mathrm{Na})$, number of effective alleles $(\mathrm{Ne})$, observed heterozygosity $(\mathrm{Ho})$, expected heterozygosity $(\mathrm{He})$, genetic differentiations among populations (FST) and historic gene flow (Nm). Significant differences between natural and planted stands were checked with t-test using SPSS 16.0 software $(P<0.01)$. Also, we used NTSYS 2.02 [17] for grouping samples.

Table 1. SSR primers used in the current study

\begin{tabular}{|c|c|c|}
\hline Marker & Primer sequence & $T\left({ }^{\circ}\right)$ \\
\hline WGA0011 & $\begin{array}{l}\text { F: ATTGGAAGGGAAGGAAATG } \\
\text { R: CGCGACATACGTAAATCAC }\end{array}$ & 58 \\
\hline WGA0041 & $\begin{array}{l}\text { F: TGTTGCATTGACCCACTTGT } \\
\text { R: TAAGCCAACATGGTATGCCA }\end{array}$ & 58 \\
\hline WGA0091 & $\begin{array}{l}\text { F: CATCAAAGCAAGCAATGGG } \\
\text { R: CCATTGCTCTGTGATTGGG }\end{array}$ & 57 \\
\hline WGA0691 & $\begin{array}{l}\text { F: TTAGTTAGCAAACCCACCCG } \\
\text { R: } \\
\text { AGATGCACAGACCAACCCTC }\end{array}$ & 58 \\
\hline WGA0712 & $\begin{array}{l}\text { F: } \\
\text { ACCCGAGAGATTTCTGGGAT } \\
\text { R: } \\
\text { GGACCCAGCTCCTCTTCTCT }\end{array}$ & 59 \\
\hline WGA0891 & $\begin{array}{l}\text { F: } \\
\text { ACCCATCTTTCACGTG } \\
\text { R: TGCCTAATTAGCAATTTCCA }\end{array}$ & 58 \\
\hline WGA118 ${ }^{1}$ & $\begin{array}{l}\text { F: TGTGCTCTGATCTGCCTCCC } \\
\text { R: GGGTGGGTGAAAAGTAGCA }\end{array}$ & 59 \\
\hline WGA202 1 & $\begin{array}{l}\text { F: CCATCTACCGTTGCACTTTT } \\
\text { R: GCTGGTGGTTCTATCATGG }\end{array}$ & 60 \\
\hline WGA276 1 & $\begin{array}{l}\text { F: CTCACTTTCTCGGCTCTTCC } \\
\text { R: GGTCTTATGTGGGCAGTCGT }\end{array}$ & 58 \\
\hline WGA3212 & $\begin{array}{l}\text { F: TCCAATCGAAACTCCAAAGG } \\
\text { R: TGTCCAAAGACGATGATGG }\end{array}$ & 57 \\
\hline
\end{tabular}




\section{RESULTS}

Results showed that the genetic diversity in natural populations is higher than in planted populations (Table 2). As the average of genetic diversity indexes in natural stands were: $\mathrm{Na}=3.97, \mathrm{Ne}=2.81, \mathrm{Ho}=0.29$ and $\mathrm{He}=0.62$ and the average of these indexes for planted populations were: $\mathrm{Na}=3.37, \mathrm{Ne}=2.60, \mathrm{Ho}=0.21$ and $\mathrm{He}=0.58$. The results showed that the genetic diversity between natural and planted populations was not significant for any parameters of genetic diversity. Totally, 119 alleles observed in natural stands which varied from 2 (WGA61 and WGA9) to 7 (WGA9). In planted stands, 101 alleles amplified which ranged from 2 (WGA321 and WGA276) to 5 (WGA202 and WGA9).

Table 2. Genetic diversity in natural and planted populations of Juglans regia based on 10 SSR primers

\begin{tabular}{lccccc}
\hline Population & $\mathrm{Na} \pm \mathrm{SE}$ & $\mathrm{Ne} \pm \mathrm{SE}$ & $\mathrm{Ho} \pm \mathrm{SE}$ & $\mathrm{He} \pm \mathrm{SE}$ & $\mathrm{F}$ \\
\hline DKH & $4.10 \pm 0.53$ & $2.64 \pm 0.29$ & $0.37 \pm 0.12$ & $0.58 \pm 0.05$ & 0.36 \\
DSK & $3.90 \pm 0.31$ & $2.76 \pm 0.16$ & $0.24 \pm 0.08$ & $0.63 \pm 0.02$ & 0.62 \\
$\mathrm{PLN}$ & $3.90 \pm 0.23$ & $3.03 \pm 0.23$ & $0.26 \pm 0.08$ & $0.65 \pm 0.03$ & 0.6 \\
Mean $\pm \mathrm{SE}$ & $3.97 \pm 0.36$ & $2.81 \pm 0.23$ & $0.29 \pm 0.09$ & $0.62 \pm 0.03$ & 0.53 \\
\hline $\mathrm{A}$ & $3.10 \pm 0.23$ & $2.39 \pm 0.21$ & $0.18 \pm 0.10$ & $0.55 \pm 0.04$ & 0.67 \\
$\mathrm{~B}$ & $3.70 \pm 0.26$ & $2.80 \pm 0.26$ & $0.25 \pm 0.08$ & $0.61 \pm 0.04$ & 0.59 \\
$\mathrm{C}$ & $3.30 \pm 0.15$ & $2.60 \pm 0.19$ & $0.21 \pm 0.07$ & $0.59 \pm 0.40$ & 0.64 \\
Mean \pm SE & $3.37 \pm 0.21$ & $2.60 \pm 0.26$ & $0.21 \pm 0.08$ & $0.58 \pm 0.16$ & 0.64 \\
\hline
\end{tabular}

The matrix of $\mathrm{F}_{\mathrm{ST}}$ and $\mathrm{Nm}$ (Table 3) among the stands showed the lowest genetic diversity is related to $\mathrm{B}$ and $\mathrm{C}$ populations. Amount of difference between them was 0.06 . The most value of $\mathrm{F}_{\mathrm{ST}}$ was observed among $\mathrm{DKH}$ and $\mathrm{C}$ populations $\left(\mathrm{F}_{\mathrm{ST}}=0.14\right)$.

Table 3. Genetic divergence (FST) and gene flow (Nm) among natural and planted populations of Juglans regia

\begin{tabular}{cllllll}
\hline & DKH & DSK & PLN & A & B & C \\
\hline DKH & 0.00 & & & & & \\
DSK & 0.11 & & & & & \\
& $(1.93)$ & 0.00 & & & & \\
PLN & 0.12 & 0.10 & & & & \\
& $(1.84)$ & $(2.24)$ & 0.00 & & & \\
A & 0.11 & 0.14 & 0.13 & 0.00 & & \\
B & $(1.54)$ & $(1.59)$ & $(1.71)$ & 0.11 & 0.00 & \\
C & 0.11 & 0.09 & 0.09 & $(1.92)$ & 0.06 & 0.00 \\
\hline
\end{tabular}

Numbers in parentheses represent the values of gene flow

The cluster analysis (UPGMA) using the Dice similarity coefficient placed both natural and planted populations in two main group (Figure 1). The first group included samples of both natural and planted stands and the second group contains fewer numbers of trees that in this group the samples of DSK and pole PLN not found.

Generally, it shows no significant genetic distance between natural and planted stands. The grouping result is consistent with the genetic diversity indices found in this study. 


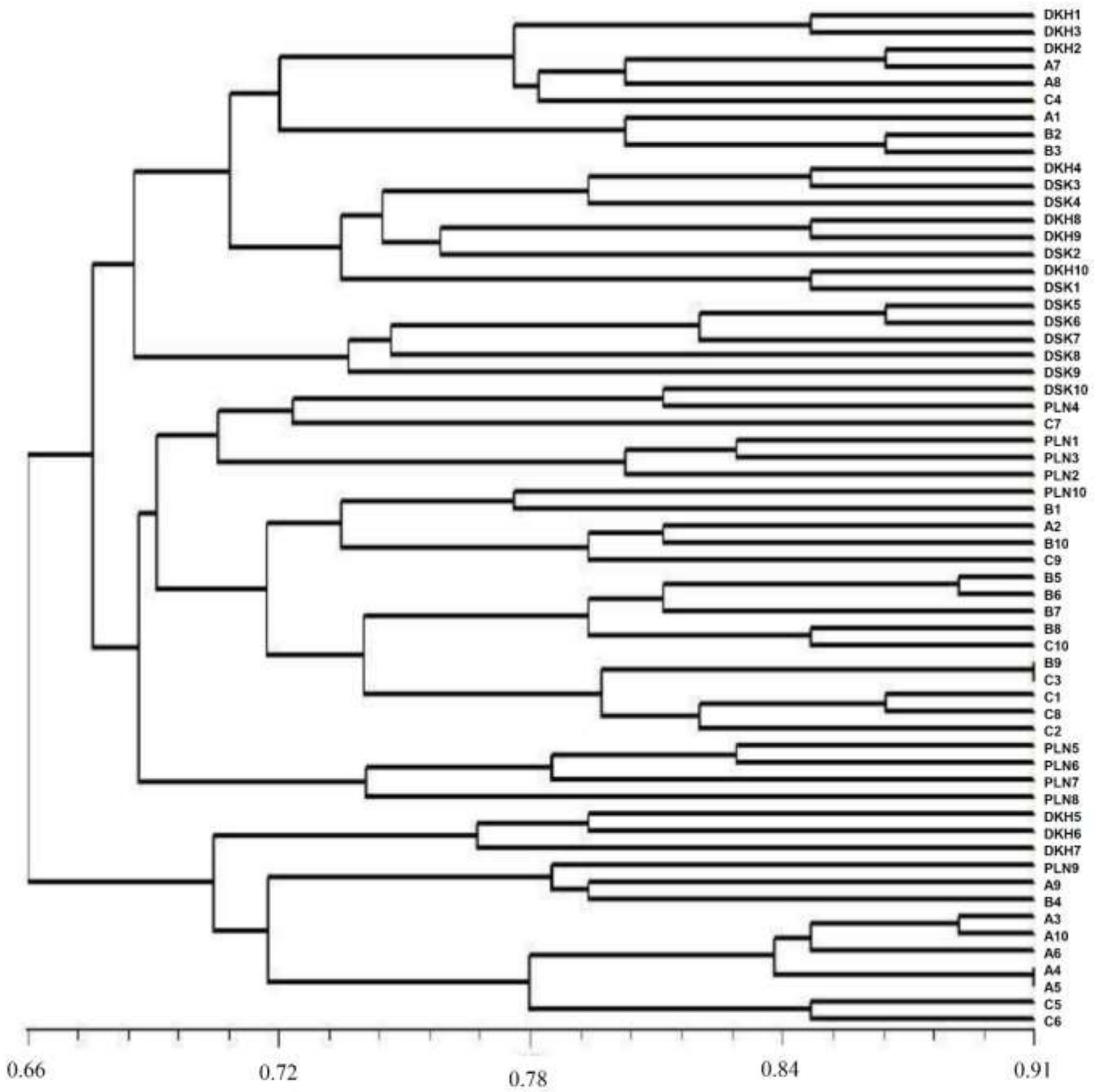

\section{Coefficient}

Figure 1. UPGMA dendrogram of six stands. DKH, DSK and PLN are natural stands; $A, B$ and $C$ are planted stands.

\section{DISCUSSION}

In a study that was about genetic diversity of walnut using SSR marker with 21 primers, the number of observed alleles (135) and heterozygosity $(\mathrm{Ho}=0.6)$ was higher than these indexes of the present study, which could be due to the large number of primers used. It is worth mentioning that in that study, all primers of the present study were used [18]

According to the unstable effects of climate, the resistance in opposition with this instability is a prominent point in forest [19], the capability of the population for confronting with environmental changes and promoting the resistance in opposition with these changes is related to having a high diversity genetic in natural and planted stands. A lot of study regarded with the assessment of the diversity of natural stands has been done which has shown different results [20-21]. Assessing the natural and planted stands of walnut (J. regia) 
situated next to each other, it showed that the genetic diversity in natural stands is higher than in planted populations. But assessing the importance of this variability using the T-test showed not remarkable difference in the genetic diversity factors. The little distance among the assessing stands has provided the possibility of using seedlings for producing planted stands. On the other hand, gene and pollen flow during pollination and among the old trees are one of the important factors in decreasing the diversity and variability among the population of these species [22]. So, the gene flow processing is a major reason for not existing a meaningful distinction among the natural populations.

Ivetic and Devetakovic [23] reported in a review study that there is no obvious trend for reduction of genetic diversity in planted stands. In a total of 34 papers comparing genetic diversity in natural forests and planted stands of 24 tree species examined by the range of markers reviewed, in the most of cases there are no significant differences in genetic diversity between natural and planted forests, followed by an almost equal cases with decreased and increased level of genetic diversity [23].

This result has a large similarity with natural and planted stand of Pinus roxburghii Sarg. in Nepal by Gauli et al. [24]. In studying these population, there was no significant difference among natural and planted stands in their genetic structure that the cause of the similarity of these stands is the little distance among these inspected stands. In addition, the study on natural and planted populations of Dalbergia sisso Roxb. by Pandey et al. [25] in Nepal indicated a remarkable difference among the natural and planted stands in spite of the fact that these stands are next to each other. The natural stands are the main source for the creation forest that there is no certain schedule for providing seedlings for reforestation. So, the excessive harvesting of seedlings from natural stands is due to decrease in the genetic diversity of natural stands. Creating planted stands from collecting seedlings of different places has caused the increase in diversity of these stands [3]. Parallel with the results in the current study, the inspection of natural and planted population by Stefanon et al. [3], the genetic diversity of Araucaria angustiflia Bertol. populations by using AFLP and SSR was inspected which signalers of microsatellite showed the existing diversity of planted stands more than that of natural stands. But AFLP signalers in natural stands showed higher genetic diversity. There was no genetic significance in any of these markers. The high genetic diversity in natural stands maybe is related to high diversity in natural stands that the seedlings are chosen or maybe it is concerned with the diversity in choosing seedling from different places for making planted stands [3].

The investigation of genetic diversity of Metasequoia glyptostroboides Hu et Cheng. in natural stands by Li et al. [26] indicated that the diversity in natural stands meaningfully was higher than the diversity in planted stands. In present study investigating the genetic distance among natural and planted stands showed the genetic distance among natural and planted population. The significant difference between natural and planted stands in this study is in contrast with the results of investigation of natural and planted stands in the current study over the walnut but the genetic distance of natural and planted stands of the walnut also is higher than the genetic distance among the planted stands.

In studying the genetic diversity of Pinus sylvestris L. stands under management and planted stands by Garcia Gil et al. [27], the genetic diversity is similar in both natural stands and those with managed regeneration, probably because regeneration practices did not decrease the population size to a point where random drift effects might be important. In current study the possibility of providing seedling from natural stands for making planted stands is not too much restricted and therefor has caused to the genetic diversity among planted stands. The comparison between genetic diversity of natural and planted stands on Albizia julibrissin Durazz. by Huh and Huh [28] indicated that the genetic diversity among the planted stands was lower than that in natural stands which the existing difference in genetic diversity was significant. In this study, the planted stands near to the urban regions had a lowest genetic diversity. With increasing the distance from natural stands, the genetic diversity of these stands decreased. In most studies done for compression the genetic diversity of natural and planted stands, the highest genetic diversity was observed in natural stands. However, the similarity of genetic diversity between natural and planted stands is indicative of considering the preservation of genetic diversity in making planted stands. Making stands with high genetic diversity increase the resistance against environmental dangers. Using the multi-purpose trees such as walnut has caused the human interference and increase breaking the harmony among these populations; hence the proper management of these sources can be a good factor in protecting these stands. 


\section{CONCLUSION}

A high value of genetic diversity is needed to keep in conservation forests with long rotations, particularly if these planted stands will be used as seed sources for next generations by planting or by natural regeneration [23]. The result of this study showed that due to the genetic similarity of natural and planted stands, the planted stands can be used as an effective factor in extending and preserving the genetic diversity.

Funding: This research was funded by Iran, Ministry of Science, Research and Technology.

Acknowledgments: We thank to Institute of Biotechnology of Urmia University for laboratory equipment.

Conflicts of Interest: "The authors declare no conflict of interest."

\section{REFERENCES}

1. FAO. Global forest resources assessment 2010 main report. FAO For Pap. 2010; 163: p. 374.

2. Al-Hawija BN, Wagner V, Hensen I. Genetic comparison between natural and planted populations of Pinus brutia and Cupressus sempervirens in Syria. Turk J Agric For. 2014; 38:267-80.

3. Stefenon VM, Gailing O, Finkeldy R. Genetic structure of plantations and the conservation of genetic resources of Brazilian pine (Araucaria angustifolia). For Ecol Manag. 2008; 255:2718-25.

4. Finkeldey R, Hattemer HH. Tropical forest genetics. Berlin: Springer-Heidelberg; 2007.

5. Kavaliauskas D, Fussi B, Westergren M, Aravanopoulos F, Finzgar D, Baier R, et al. The Interplay between forest management practices, genetic monitoring, and other long-term monitoring systems. Forests. 2018; 9(133):1-22.

6. Weising K, Nybom H, Wolff K, Meyer W. DNA fingerprinting in plant and fungi. 2nd ed. Boca Raton: CRC press; 1995.

7. Zhang R, Zhu A, Wang X, Yu J, Zhang HR, Gao JS, et al. Development of Juglans Regia SSR Markers by Data Mining of the EST Database. Plant Mol Biol Rep. 2010; 28:646-53.

8. Fraser LG, Harrey CF, Crowhurst RN, De Silva HN. EST-derived microsatellites from Actinidia species and their potential for mapping. Theor Appl Genet. 2004;108:1010-6.

9. Aggarwal RK, Hendre PS, Varshney RK, Bhat PR, Krishnakumar V, Singh L. Identification, characterization and utilization of EST-derived genic microsatellite markers for genome analyses of coffee and related species. Theor Appl Genet. 2007; 114 (2): 359-72.

10. Pollegioni $P$, Woeste K. Retrospective identification of hybridogenic walnut plants by SSR fingerprinting and parentage analysis. Mol Breed. 2009; 24: 321-35.

11. Ciarmiello LF, Piccirillo P, Pontecorvo G, Luca AD, Kafantaris I, Woodrow P. A PCR based SNPs marker for specific characterization of English walnut (Juglans regia L.) cultivars. Mol Biol Rep. 2011; 38: 1237-49.

12. IUCN. IUCN Red List of Threatened Species. www.iucnredlist.org. 2016.

13. Doyle JJ, Doyle JL. Isolation of plant DNA from fresh tissue. Focus. 1990; 12: 13-5.

14. Dangl GS, Woeste K, Aradhya MK, Koehmstedt A, Simon C, Potter D, Leslie C, McGranahan GH. Characterization of 14 microsatellite markers for genetic analysis and cultivar identification of walnut. J Am Soc Hortic Sci. 2005; 130: 348-54.

15. Woeste K, Burns R, Rhodes O, Michler C. Thirty polymorphic nuclear microsatellite loci from black walnut. J Hered. 2002; 93: 5-60.

16. Peakall R, Smouse PE. GENALEX 6.4: Genetic analysis in Excel. Population genetic software for teaching and research. Mol Ecol Notes. 2006; 6: 288-95.

17. Rohlf FJ. NTSYS-pc version 2.0. Numerical taxonomy and multivariate analysis system, New York-Setauket: Exeter Software;1998.

18. Orhan E, Eyduran SP, Poljuha D, Akin M, Weber T, Ercisli S. Genetic diversity detection of seed-propagated walnut (Juglans regia L.) germplasm from Eastern Anatolia using SSR markers. Folia Hortic. 2020; 32(1): 1-10.

19. Matyas C. Expected climate instability and its consequences for conservation of forest genetic resources. In: Geburek T, Turok J, editor. Conservation and Management of Forest Genetic Resources in Europe. Zvolen: Arbora publishers; 2005.

20. Medri C, Ruas PM, Higa AR, Murakami M, Ruas CF. Effects of forest management on the genetic diversity in a population of Araucaria angustifolia (Bert). O. kuntze. Silvae Genet. 2003; 52: 202-5.

21. Korshikov II, Ducii F, Terliga NS, Bichkov SS, Gorlova EM. Allozyme variation of Pinus pallasiana D. Don in natural crimean populations and in technogenously polluted areas of the Ukraine steppes. Ann For Sci. 2004; 61: 389-96.

22. Austerlitz F, Mariette S, Machon N, Gouyon PH, Godelle B. Effects of colonization processes on genetic diversity: differences between annual plants and tree species. Genetics. 2000; 154: 1309-21.

23. Ivetic V, Devetakovic J. Concerns and evidence on genetic diversity in planted forests. Reforesta. 2017; 3: 196-207. 
24. Gauli A, Gailing O, Stefenon VM, Finkeldey R. Genetic similarity of natural populations and plantations of Pinus roxburghii sarg Nepal. Ann For Sci. 2009; 66: 703-12.

25. Pandey M, Gailing O, Leinemann L, Finkeldy R. Molecular markers provide evidence for long-distance planting material transfer during plantation establishment of Dalbergia sisso Roxb. in Nepal. Ann For Sci. 2004; 61: 603-6.

26. Li YY, Chen XY, Zhang X, Wu TY, Lu HP, Cai YW. Genetic differences between wild and artificial population of Metasequoia glyptostrboides implicationforspecies recovery. Conserv Biol. 2005; 19: 224-31.

27. Garcia Gil MR, Floran V, Östlund L, Mullin TJ, Andersson Gull B. Genetic diversity and inbreeding in natural and managed populations of Scots pine. Tree Genet Genomes. 2015; 11(28): 1-12.

28. Huh MK, Huh HW. Genetic diversity and population structure of silk tree (Albiziz julibrissin Durazz.) in Korea. For Genet. 2000; 7(1): 1-9.

(C) 2021 by the authors. Submitted for possible open access publication under the terms and conditions of the Creative Commons Attribution (CC BY NC) license (https://creativecommons.org/licenses/by-nc/4.0/). 